\title{
Ragi Husk as Substrate for Cellulase Production Under Temperature Mediated Solid State Fermentation by Streptomyces Sp
}

\author{
Totiya Ishchi ${ }^{1}$, Sibi G. ${ }^{2}$ \\ ${ }^{1}$ Department of Biology, Education Faculty, Jawzjan University, Sheberghan City, Afghanistan \\ ${ }^{2}$ Department of Biotechnology, Indian Academy Degree College-Autonomous, Bengaluru, India
}

Email address:

gsibii@gmail.com (Sibi G.)

\section{To cite this article:}

Totiya Ishchi, Sibi G. Ragi Husk as Substrate for Cellulase Production Under Temperature Mediated Solid State Fermentation by Streptomyces Sp. American Journal of BioScience. Vol. 7, No. 4, 2019, pp. 77-81. doi: 10.11648/j.ajbio.20190704.11

Received: October 8, 2019; Accepted: October 26, 2019; Published: October 31, 2019

\begin{abstract}
Cellulases have diversity of industrial applications and their cost effective production using agroindustrial wastes by solid state fermentation poses an efficient method. Actinomycetes are considered highly valuable due to their secondary metabolites production and in this study, an attempt was made to optimize the use of ragi husk and refine the process of cellulase production by temperature mediated solid state fermentation. Actinomycetes were isolated from paper mill industry soil and cellulase producing Streptomyces sp was selected for the experiments. Ragi husk was used as substrate for solid state fermentation of cellulase and varying incubation temperatures $\left(20^{\circ} \mathrm{C}, 25^{\circ} \mathrm{C}, 30^{\circ} \mathrm{C}, 35^{\circ} \mathrm{C}\right.$ and $\left.40^{\circ} \mathrm{C}\right)$ was considered to determine its effect on enzyme activity after $6^{\text {th }}, 9^{\text {th }}$ and $12^{\text {th }}$ day of fermentation. The carboxymethyl cellualse (CMC-ase) activity was measured and the observations obtained were compared with the standard glucose curve to determine the amount of reducing sugar $\left(\mu \mathrm{g} \mathrm{ml}^{-1}\right)$ released. Enzyme activity was highest at $35^{\circ} \mathrm{C}$ and was recorded as $35.14,45.90$ and $59.56 \mathrm{IU} \mathrm{ml}^{-1}$ at the end of $6^{\text {th }}, 9^{\text {th }}$ and $12^{\text {th }}$ day of fermentation. Highest amount of reducing sugars at a concentration of $322 \mu \mathrm{g} \mathrm{m} l^{-1}$ was released at the end of $12^{\text {th }}$ day at $35^{\circ} \mathrm{C}$. The results indicated that the enzyme activity was temperature dependent while using ragi husk as growth substrate under solid state fermentation.
\end{abstract}

Keywords: Cellulase, Streptomyces, Solid State Fermentation, Agroindustrial Wastes, Ragi Husk, Actinomycetes

\section{Introduction}

Cellulose, a linear polymer of glucose molecules joined by $\beta$-1,4-glycosidic-linkages, is the most abundant biopolymer on the planet and strongly resistant to biodegradation [1]. Cellulose is commonly degraded by cellulases $(\beta-1,4$ glucan hydrolases) that hydrolyze cellulose and produce as primary products glucose, cellobiose and cello-oligosaccharides. They are a group of enzymes which act synergistically on cellulose to bring about its hydrolysis and are currently the subject of numerous studies due to their importance in biomass hydrolysis.

Cellulases have attracted much interest because of the diversity of their application. The major industrial applications of cellulases are in textile industry for biopolishing of fabrics and producing stonewashed look of denims, as well as in household laundry detergents for improving fabric softness, brightness and anti-deposition. Besides, they are used in animal feeds [2] for improving the nutritional quality and digestibility, in processing of fruit juices and in baking, while de-inking of paper is yet another emerging application. Because of its commercial importance and complexity of structure, research of many labs and industries are revolving around cellulase producing microbes. Cellulases are produced by fungi [3-6], bacteria [7, 8] and actinomycetes [9-11]. Though several microorganisms produce cellulases, relatively few numbers of fungi and bacteria are known to produce the enzymes in high levels. Actinomycetes are Gram positive, filamentous, spore forming, aerobic bacteria. Actinomycetes are considered highly valuable as they produce various secondary metabolites and other biologically useful compounds such as antibiotics, vitamins, nutritional materials, herbicides, pesticides and enzymes [12-14]. They are able to metabolize 
various compounds of complex structures by the production of extracellular enzymes [15].

Millets are cultivated in a wide range of soils and climates because of their hardy nature and short growing seasons making them important crops in semi-arid regions, worldwide. Millet bran, by-product of milling process is an ideal, cheaper source and mainly used as animal feed due to their high nutritive value and low costs. Finger millet (Eleusine coracana) locally known as Ragi is predominantly starchy and improve the $\mathrm{C} / \mathrm{N}$ ratio, presenting ideal conditions for growth of microbes. Efforts have been made to obtain a low cost cellulase, using different technologies and substrates. In this context, ragi husk appear as ideal substrate for microbial fermentation, due to their rich content of organic components, low cost and wide availability. Furthermore, the use of agricultural by-products presents a better energy balance and a lower environmental impact than those of pure substrates [16].

Solid state fermentation (SSF) has been described as the process that takes place in a solid matrix (inert support or support/substrate) in the absence or near absence of free water [17], but the substrate requires moisture to support the growth and metabolic activity of microorganisms [18]. Solid state fermentation is a suitable strategy for producing low cost enzymatic products. Nutrients present in the substrate support growth and due to the natural metabolism of the microorganism, can secrete enzymes, while growing in the solid substrate [19]. Here, an attempt was made to optimize the use of ragi husk and refine the process of cellulase using actinomycetes, so as to enhance the end product output that is to maximize the yield of cellulase by temperature mediated solid state fermentation.

\section{Materials and Methods}

\subsection{Isolation of Actinomycetes}

Soil samples were collected from paper mill industry located at outskirts of Bangalore. Starch-casein-agar was used to isolate actinomycetes colonies from the soil and the media was supplemented with rifampicin and cycloheximide at $50 \mu \mathrm{g} \mathrm{ml}^{-1}$ concentration. To isolate actinomycetes, $5 \mathrm{~g}$ of screened soil ( $1 \mathrm{~mm}$ sieve) were added to $50 \mathrm{ml}$ sterile water and shaken at $140 \mathrm{rpm}$ for $20 \mathrm{~min}$. Ten fold dilutions were prepared from the resulting suspension and was serially diluted up to $10^{-10}$ with sterile distilled water. One $\mathrm{ml}$ of each dilution was spread on the surface of starch casein agar plate containing $20 \mathrm{ml}$ of each medium. After 7 days of incubation, the colonies showing the characteristics of actinomycetes were observed. The pure culture was maintained as a spore suspension in $20 \%$ glycerol at $-20^{\circ} \mathrm{C}$.

\subsection{Primary Screening of Isolates for Production of Cellulase}

CMC Agar (carboxymethylcellulose $0.5 \mathrm{gL}^{-1}, \mathrm{NaNO}_{3} 0.1$ $\mathrm{gL}^{-1}, \mathrm{~K}_{2} \mathrm{HPO}_{4} 0.1 \mathrm{gL}^{-1}, \mathrm{MgSO}_{4} 0.05 \mathrm{gL}^{-1}$, yeast extract 0.05 $\mathrm{gL}^{-1}$, Agar $15 \mathrm{gL}^{-1}$ ) was used for cellulose degrading efficiency test [2]. The selection of cellulase producers was based on the extent of production of clear zones on CMC agar when treated with $1 \%$ Congo red dye (w/v) followed by $1 \mathrm{~N} \mathrm{HCl}$ for $15-20 \mathrm{~min}$.

\subsection{Characterization of Cellulase Producing Actinomycete}

The actinomycete colony selected from primary screening was identified based on cultural and morphological characteristics according to standard protocols of International Streptomyces Project [20]. The cultural characteristics such as colour of substrate and aerial mycelia, growth pattern, colony texture, and colony reverse colour were examined [21].

\subsection{Inoculum and Substrate Preparation}

A loopful of actinomycetes culture was transferred to 10 $\mathrm{ml}$ of autoclaved water and used as inoculum. $40 \mathrm{~g}$ of ragi husk was taken in a $250 \mathrm{ml}$ flask and $40 \mathrm{ml}$ of minimal salt media $\left[\mathrm{Na}_{2} \mathrm{HPO}_{4} \cdot 2 \mathrm{H}_{2} \mathrm{O}-1.1 \mathrm{~g}, \mathrm{NaH}_{2} \mathrm{PO}_{4} \cdot 2 \mathrm{H}_{2} \mathrm{O}-0.61 \mathrm{~g}, \mathrm{KCl}-\right.$ $0.3 \mathrm{~g}, \mathrm{MgSO}_{4} \cdot 7 \mathrm{H}_{2} \mathrm{O}-0.01 \mathrm{~g}, \mathrm{pH}-7$, Distilled water-100 ml] was added $(1: 1 \mathrm{w} / \mathrm{v})$. The moisture content was maintained at optimum levels and the contents of the flask were autoclaved at $121^{\circ} \mathrm{C}$ for $20 \mathrm{mins}$.

\subsection{Solid State Fermentation}

After autoclaving, the contents of the flask was inoculated with $1.0 \times 10^{7} \mathrm{cfu} / \mathrm{ml}$ of 7 days old culture of Streptomyces sp and incubated under static conditions. Varying incubation temperatures $\left(20^{\circ} \mathrm{C}, 25^{\circ} \mathrm{C}, 30^{\circ} \mathrm{C}, 35^{\circ} \mathrm{C}\right.$ and $\left.40^{\circ} \mathrm{C}\right)$ was considered to determine its effect on enzyme activity after $6^{\text {th }}, 9^{\text {th }}$ and $12^{\text {th }}$ day of fermentation from $40 \mathrm{~g}$ of substrate used. Each experiment was done in triplicates. At the end of fermentation period, $50 \mathrm{ml}$ of citrate buffer $(\mathrm{pH} \mathrm{4.8)}$ was added to the cultured flasks followed by filtration through 0.5 $\mathrm{mm}$ nylon cheese cloth. The filtrate was centrifuged at 10000 rpm for 5 mins and the cell-free culture supernatant was used as the source of enzyme.

\subsection{Enzyme Assay}

Carboxymethyl cellulase (CMC-ase) activity was assayed using the method described earlier [22]. $0.5 \mathrm{ml}$ of enzyme solution was added to $0.5 \mathrm{ml}$ of $0.55 \%(\mathrm{w} / \mathrm{v})$ of carboxy methylcellulose prepared in sodium citrate buffer $(\mathrm{pH} 4.8)$ and incubated at $37^{\circ} \mathrm{C}$ for $60 \mathrm{~min}$. The reaction was stopped by adding $1.0 \mathrm{ml}$ of 3,5-dinitro salicylic acid (DNSA) reagent to the mixture followed by boiling for $10 \mathrm{~min}$ and adding 8.0 $\mathrm{ml}$ of distilled water. The Optical Density of the mixture was recorded at $540 \mathrm{~nm}$ using a UV-Vis spectrophotometer and compared with the standard glucose curve to determine the amount of reducing sugar $\left(\mu \mathrm{g} \mathrm{ml} \mathrm{ml}^{-1}\right)$ produced during cellulose hydrolysis.

\subsection{Reducing Sugars Content Assay}

The cellulase activity of actinomycete was measured by determining the amount of reducing sugars liberated by using 
a di-nitro salicylic acid (DNSA) colorimetric method [23]. Reducing sugars analysis was conducted by using $2 \mathrm{ml}$ of sample which was added to $3 \mathrm{ml}$ of DNS and boiled for 15 min. After cooling, $1 \mathrm{ml}$ of Rochelle salt solution was added followed by measuring the absorbance at $575 \mathrm{~nm}$ using a spectrophotometer against the blank of distilled water.

\section{Results and Discussion}

Actinomycetes colony obtained in starch casein nitrate agar was purified by streaking (Figure 1) and the colony that has produced clear zone around in CMC agar (Figure 2) upon addition of congo red was further identified by cultural and morphological characteristics. The results revealed that the colony belongs to Streptomyces sp which was further used for cellulase production. Ragi husk was used as substrate to produce cellulase enzyme by solid state fermentation under varying temperature. The enzyme was recovered from the fermentation media by adding citrate buffer $(\mathrm{pH} 4.8)$ and the crude enzyme was used for enzyme assay.

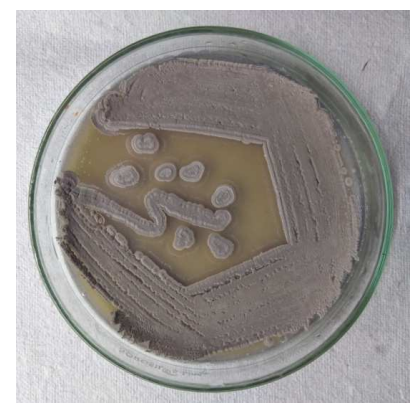

Figure 1. Actinomycete isolate from paper mill industry soil.

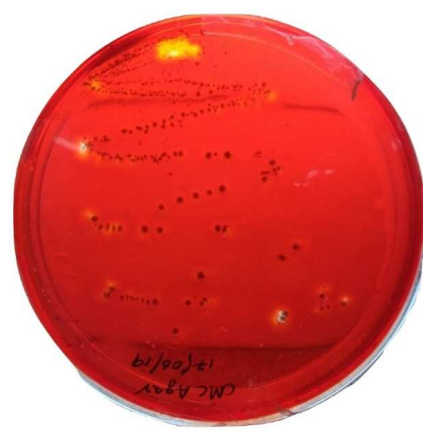

Figure 2. CMC-ase activity (zone of hydrolysis) of the isolate upon addition of congo red solution.

Environmental variables significantly influence microbial growth and product formation in SSF. This work sought to address the optimum temperature for the production of cellulase activity recorded at different temperatures. Optimal temperature for cellulase enzyme production by Streptomyces was recorded at temperatures $25^{\circ} \mathrm{C}, 30^{\circ} \mathrm{C}, 35^{\circ} \mathrm{C}, 40^{\circ} \mathrm{C}$ and $45^{\circ} \mathrm{C}$ on $6^{\text {th }}, 9^{\text {th }}$ and $12^{\text {th }}$ day of incubation using ragi husk as growth substrate. The CMC-ase activity was measured and the observations obtained were compared with the standard glucose curve to determine the amount of reducing sugar $(\mu \mathrm{g}$ $\mathrm{ml}^{-1}$ ) released. The result of investigation carried out in this study on effect of temperature on cellulase by Streptomyces sp is depicted in Figure 3. Cellulase assay indicated that the enzyme activity was temperature dependent and the activity was increased when the fermentation temperature was increased through $25^{\circ} \mathrm{C}$ to $35^{\circ} \mathrm{C}$. In all the time intervals tested $\left(6^{\text {th }}, 9^{\text {th }}, 12^{\text {th }}\right.$ day $)$, the enzyme activity was highest at $35^{\circ} \mathrm{C}$ and was in the range of 35.14-59.56 $\mathrm{IU} \mathrm{ml}^{-1}$. The activity was reduced when the temperature was increased from $35^{\circ} \mathrm{C}$ to $40^{\circ} \mathrm{C}$, however, it started increasing again when the temperature was set as $45^{\circ} \mathrm{C}$ at the end of $6^{\text {th }}$ day. The release of reducing sugars was determined by DNSA method and the results indicated that highest amount of reducing sugars at a concentration of $322 \mu \mathrm{g} \mathrm{ml}^{-1}$ was released at the end of $12^{\text {th }}$ day at $35^{\circ} \mathrm{C}$. It was also noted that at the end of 6 days of fermentation, more amount of reducing sugars were $\left(216 \mu \mathrm{g} \mathrm{ml}^{-1}\right)$ released at $45^{\circ} \mathrm{C}$ (Figure 4).

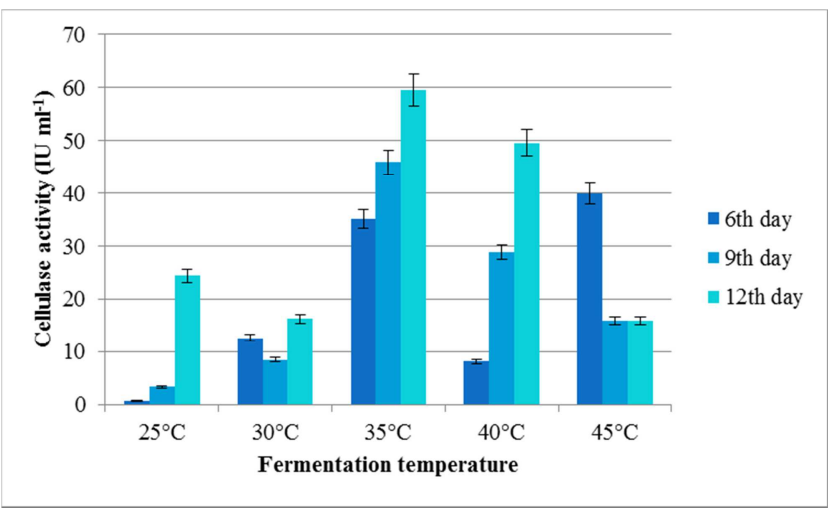

Figure 3. Cellulase activity of Streptomyces sp under varying fermentation temperature using ragi husk as growth substrate.

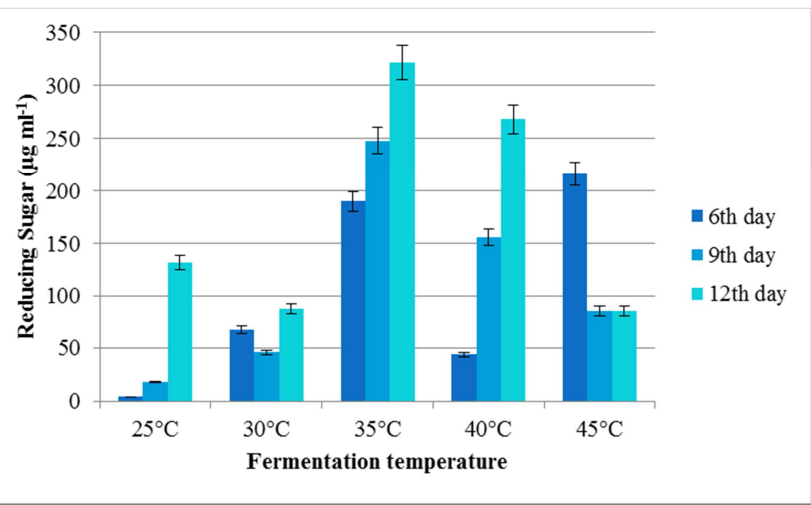

Figure 4. Reducing sugar release by Streptomyces sp under varying fermentation temperature using ragi husk as growth substrate.

The use of agro-industrial residues and by-products as feedstock enriches the SSF processes economic value. The substrates used in SSF make the process eco-friendly because it also solves the problem of their disposal, which otherwise would cause pollution. The genus Streptomyces is widely found in soils and it is well known for its production of many extracellular enzymes, including those involved in the degradation of cellulose, hemicellulose and lignin, the three primary plant cell-wall polymers [24-26]. Streptomyces sp. are also indicated for SSF processes since they present characteristics such as abundant colonization of solid 
residues, production of a wide range of degradative enzymes and high resistance to extreme conditions [27].

Optimization of environmental variables and culture medium factors is a key concern for the development of suitable biotechnology for cellulase production [28]. Temperature significantly influenced the growth, development and, in general, metabolic activities of an organism. Hence, it was essential to optimize temperature for maximum cellulase production in Streptomyces under SSF, using ragi husk as substrate. In this study, temperature was found to influence extracellular enzyme secretion and $35^{\circ} \mathrm{C}$ was found optimum for cellulase production by Streptomyces sp. In a study by Prasad et al., [29], Streptomyces griseorubens showed highest cellulolytic activity at $45^{\circ} \mathrm{C}$ on $6^{\text {th }}$ day of incubation period. In another study, Streptomyces sp. secreted on third day $(0.19 \pm 0.005 \mathrm{U} / \mathrm{gds})$ of fermentation [30].

Incubation temperature is paramount for optimal enzyme production due to alterations in microbial protein structure and properties with temperature variations [31]. Previous studies have reported optimum temperatures of $30^{\circ} \mathrm{C}$ for cellulase production by two Streptomyces strains [32]. In addition, Jaradat et al., [33] also reported optimal temperature of $30^{\circ} \mathrm{C}$ for cellulase production by Streptomyces sp. strain J2. It was revealed from the study that although optimal cellulase production was recorded at temperature of $35^{\circ} \mathrm{C}$ with activity of $59.56 \mathrm{U} \mathrm{ml}^{-1}$, production was also recorded at all the incubation temperatures tested. Other temperatures at which cellulase production was recorded in order of descent are: $45,30,25$ and $40^{\circ} \mathrm{C}$ with activity at the end of 12 days. Fatokun et al., [34] reported that cellulase production was optimal at incubation temperature of $40^{\circ} \mathrm{C}$ and $0.26 \mathrm{U} \mathrm{ml}^{-1}$ activity was attained at $60 \mathrm{~h}$ with specific productivity of $205 \mathrm{U} \mathrm{g} \mathrm{g}^{-1}$.

\section{Conclusion}

Optimal condition for cellulase production by Streptomyces was investigated by measuring cellulase activity at the varied incubation temperature conditions at different time intervals. Enzyme production was favored by $35^{\circ} \mathrm{C}$ incubation temperature during the 12 days fermentation time. Furthermore, the strain was able to produce higher amounts of cellulase using ragi husk as growth substrate under solid state fermentation. In this work, both the cultivation and fermentation conditions were optimized to enhance the cellulase production by Streptomyces and the cellulolytic potential of the isolate could be beneficial in hydrolysis of the cellulosic materials.

\section{References}

[1] O'Sullivan, A. C. (1997). Cellulose: the structure slowly unravels. Cellulose. 4: 173-207.

[2] Kasana, R. C., Salwan, R., Dhar, H., Dutt, S., Gulati, A. (2008). A rapid and easy method for the detection of microbial cellulases on agar plates using gram's iodine. Curr. Microbiol. 57: 503-507.

[3] Callow, N., Ray, C. S., Kelby, M. A., Ju, L. K. (2016). Nutrient control for stationary phase cellulase production in Trichoderma reesei Rut C30. Enzyme Microb. Technol. 82: 814.

[4] Sharma, B., Agrawal, R., Singhania, R. R., Satlewal, A., Mathur, A., Tuli, D., Adsul, M. (2015). Untreated wheat straw: potential source for diverse cellulolytic enzyme secretion by Penicillium janthinellum EMS-UV-8 mutant. Bioresour. Technol. 196: 518-524.

[5] Saini, R., Saini, J. K., Adsul, M., Patel, A. K., Mathur, A., Tuli, D., Singhania, R. R. (2015). Enhanced production by Penicillium oxalicum for bio-ethanol application. Bioresour. Technol. 188: 240-246.

[6] Lan, T. Q., Wei, D., Yang, S. T., Liu, X. (2013). Enhanced cellulase production by Trichoderma viride in a rotating fibrous bed bioreactor. Bioresour. Technol. 133: 175-182.

[7] Assareh, R., Zahiri, H. S., Noghabi, K. A., Aminzadeh, S., Khaniki, B. (2012). Characterization of newly isolated Geobacillus sp. T1, the efficient cellulase producer on untreated barley and wheat straws. Bioresour. Technol. 120: 99-105.

[8] Rastogi, G., Bhalla, A., Adhikari, A., Bischoff, K. M., Hughes, S. R., Christopher, L. P., Sani, R. K. (2010). Characterization of thermostable cellulases produced by Bacillus and Geobacillus strains. Bioresour. Technol. 101: 8798-8806.

[9] Mohanta, Y. K. (2014). Isolation of cellulose degrading actinobacteria and evaluation of their cellulolytic potential. Bioeng. Biosci. 1: 1-5.

[10] Cirigliano, M. N. F., Rezende, R. D. C., Oliveira, M. N. G., Pereira, P. H. F., Nascimento, R. P. D., Bon, E. P. D. S., Macrae, A., Coelho, R. R. R. (2013). Streptomyces misionensis PESB25 produces a thermoacidophilic endoglucanase using sugarcane bagasse and corn steep liquor as the sole organic substrates. Hindawi Publishing Corporation Biomed Research International (ID 584137, pp. $1-9)$.

[11] Sarita, M., Arora, A., Singh, S., Nain, L. (2013). Streptomyces griseorubens mediated delignification of paddy straw for improved enzymatic saccharification yields. Bioresour. Technol. 135: 12-17.

[12] Berdy, J. (2012). Thoughts and facts about antibiotics: Where We Are Now and Where We Are Heading. J. Antibiot., 65 (8): 385-395.

[13] Mohseni, M., Norouzi, H., Hamedi, J., Roohi, A. (2013). Screening of antibacterial producing Actinomycetes from sediments of the Caspian Sea. Int. J. Mol. Cell Med. 2: 64-71.

[14] Abdelmohsen, U. R., Grkovic, T., Balasubramanian, S., Kamel, M. S., Quinn, R. J., Hentschel, U. (2015). Elicitation of secondary metabolism in actinomycetes. Biotechnol. Adv. 33: 798-811.

[15] Antonopoulos, V. T., Hernandez, M., Arias, M. E., Mavrakos, E., Ball, A. (2001). The use of extracellular enzymes from Streptomyces albus ATCC 3005 for the bleaching of Eucalyptus kraft pulp. Appl. Microbiol. Biotechnol., 57: 92-97. 
[16] Olofsson, K., Bertilsson, M., Liden, G. (2008). A short review on SSF - an interesting process option for ethanol production from lignocellulosic feedstocks. Biotechnol. Biofuels. 1: 1-14.

[17] Singhania, R. R., Sukumaran, K. K., Patel, A. K., Larroche, C., Pandey, A. (2010). Advancement and comparative profiles in the production technologies using solid-state and submerged fermentation for microbial cellulases. Enzyme Microb. Technol. 46: 541-549.

[18] Thomas, L., Larroche, C., Pandey, A. (2013). Current developments in solid-state fermentation. Biochem. Eng J. 81: 146-161.

[19] Kumar, A., Kanwar, S. S. (2012). Lipase production in solidstate fermentation (SSF): recent developments and biotechnological applications. Dyn Biochem, Process Biotechnol. Mol. Biol. 6: 13-27.

[20] Shirling, E. B., Gottlieb, D. (1966). Methods for characterization of Streptomyces species. Int. J. Syst. Bacteriol. 16: 313-340.

[21] Pridham, T. G. (1965). Color and Streptomycetes. Appl. Microbiol. 13: 43-61.

[22] Wood, T. M., Bhat, K. M. (1998). Method for measuring cellulase activities. W. A. Wood, J. A. Kellogg (Eds.), Methods in Enzymology: Cellulose and Hemicellulose, Academic Press, New York. 87-112.

[23] Miller, G. L. (1959). Use of dinitrosalicylic acid reagent for determination of reducing sugar. Anal. Chem. 31: 426-428.

[24] Mackenzie, C. R., Bilous, D., Schneider, H., Johnson, K. G. (1987). Induction of cellulolytic and xylanolytic enzyme systems in Streptomyces spp. Appl. Environ. Microbiol. 53: 2835-2839.

[25] Nascimento, R. P., Junior, N. A., Pereira Jr, N., Bon, E. P. S., Coelho, R. R. R. (2009). Brewer's spent grain and corn steep liquor as substrates for cellulolytic enzymes production by Streptomyces malaysiensis. Lett. Appl. Microbiol. 48: 529535.
[26] Da Vinha, F. N. M., Gravina-Oliveira, M. P., Franco, M. N., Macrae, A., Bon, E. P., Nascimento, R. P., Coelho, R. R. R. (2011). Cellulase production by Streptomyces viridobrunneus SCPE-09 using lignocellulosic biomass as inducer substrate. Appl. Biochem. Biotechnol. 164: 256-267.

[27] Orozco, A. L., Perez, M. I., Guevara, O., Rodriguez, J., Hernandez, M., Gonzalez-Vila, F. J. (2008). Biotechnological enhancement of coffee pulp residues by solid-state fermentation with Streptomyces. Py-GC/MS analysis Journal of Analytical and Applied Pyrolysis, 81:247-252.

[28] Mekala, N. K., Singhania, R. R., Sukumaran, R. K., Pandey A. (2008). Cellulase production under solid-state fermentation by Trichoderma reesei RUT C30: Statistical optimization of process parameters. Appl. Biochem. Biotechnol. 151: 122131.

[29] Prasad, P., Singh, T., Bedi, S. (2013). Characterization of the cellulolytic enzyme produced by Streptomyces griseorubens (Accession No. AB184139) isolated from Indian soil. Journal of King Saudi University - Science. 25: 245-250.

[30] Cadirci, B. H., Yasa, I., Kocyigit, A. (2014). Streptomyces sp. TEM 33 possesses high lipolytic activity in solid-state fermentation in comparison with submerged fermentation. Prep. Biochem. Biotechnol. 46: 23-29.

[31] Juturu, V., Wu, J. C. (2014). Microbial cellulases: Engineering, production and applications. Renew. Sustain. Energy Rev. 33: 188-203.

[32] Chellapandi, P., Jani, H. M. (2008). Production of endoglucanase by the native strains of Streptomyces isolates in submerged fermentation. Braz. J. Microbiol. 39: 122-127.

[33] Jaradat, Z., Dawagreh, A., Ababneh, Q., Saadoun, I. (2008). Influence of culture conditions on cellulase production by Streptomyces Sp. (Strain J2). Jordan J. Biol. Sci., 1: 141-146.

[34] Fatokun, E. N., Nwodo, U. U., Okoh, A. I. 2016. Classical optimization of cellulase and xylanase production by a marine Streptomyces species. Appl. Sci. 6: 286. 